\title{
ANALISIS MENGENAI KINERJA HIMPUNAN MAHASISWA
}

\section{ANALYSIS OF THE PERFORMANCE OF THE STUDENT ASSOCIATION}

\author{
Oktavianus Theodora Prima \\ Jurusan Sosiologi, Fakultas Ilmu Sosial dan Ilmu Politik, Universitas Sriwijaya \\ Email: oktavianusdora@gmail.com
}

\begin{abstract}
ABSTRAK
Penelitian ini bertujuan untuk menganalisis kinerja Himpunan Mahasiswa Sosiologi di masa pandemi covid - 19. Penelitian ini dilakukan secara online di ruang lingkup Himpunan Mahasiswa Sosiologi, Universitas Sriwijaya. Objek penelitian ini adalah civitas akademik yang tergabung dalam Himpunan Mahasiswa Sosiologi. Penentuan informan dilakukan dengan teknik purposive sampling, yaitu teknik pengambilan sampel sumber data dengan pertimbangan tertentu. Informan yang dipilih terdiri dari bupati Himpunan Mahasiswa Sosiologi dan badan pengurus harian Himpunan Mahasiswa Sosiologi. Teknik pengumpulan data dilakukan dengan wawancara mendalam secara online. Wawancara berdasarkan pada pedoman wawancara yang telah dibuat. Hasil penelitian menunjukkan bahwa kinerja Himpunan Mahasiswa Sosiologi mengalami penurunan selama masa pandemi covid - 19. Penurunan kinerja dibuktikan masih terdapat program kerja yang belum terlaksana, bahkan gagal untuk dilaksanakan. Terhitung dari bulan Maret hingga sekaramg terdapat lima program kerja yang telah terlaksana secara online. Dalam perubahan sistem pelaksanaan dari offline ke online oleh Himpunan Mahasiswa Sosiologi memerlukan penyesuain dalam pelaksanaan program kerja di masa pandemi covid - 19.
\end{abstract}

Kata kunci: Kinerja, Himpunan mahasiswa sosiologi, Pandemi Covid - 19, Program kerja.

\begin{abstract}
This study aims to analyze the performance of Himpunan Mahasiswa Sosiologi in the Covid-19 pandemic. This research was conducted online within the scope of Himpunan Mahasiswa Sosiologi, Sriwijaya University. The object of this research is the members of Himpunan Mahasiswa Sosiologi. The determination of the informants was done by using purposive sampling technique, the technique of taking the sample of data sources with certain considerations. The selected informants consisted of the regents of Himpunan Mahasiswa Sosiologi and the management of Himpunan Mahasiswa Sosiologi. The data collection technique was carried out by in-depth interviews online. The interview is based on the interview guidelines that have been made. The results showed that the performance of Himpunan Mahasiswa Sosiologi had decreased in the Covid-19 pandemic. A decrease in performance evidenced still there is a work program that has not been done, even failed to be implemented. Starting from March up to now there are five programs of work that has been accomplished online. In the system change of implementation of offline to online from Himpunan Mahasiswa Sosiologi require adjustments in the running of the work program in the covid - 19 pandemic.
\end{abstract}

Keywords: Performance, Himpunan mahasiswa sosiologi, Covid - 19 Pandemic, Program basics 
P-ISSN 2580 - 7781

E-ISSN 2615 - 3238

\section{PENDAHULUAN}

Perguruan tinggi merupakan institusi pendidikan yang memiliki peran dalam pengembangan sumber daya manusia dan menciptakan agent of change. Sebagai agent of change peserta didik yakni mahasiswa diharapkan mampu memberikan kontribusi dan perubahan bagi kemajuan bangsa. Dalam proses pengembangan sumber daya manusia perguruan tinggi tidak hanya memberikan fasilitas berupa kegiatan akademik, tetapi juga kegiatan non akademik. Kegiatan non akademik didapatkan mahasiswa melalui organisasi kemahasiswaan yang telah dibentuk di lingkungan kampus.

Menurut Menteri Pendidikan dan Kebudayaan Nomor 155/U/1998 tentang Pedoman Umum Organisasi Kemahasiswaan, dijelaskan bahwa organisasi kemahasiswaan adalah wahana dan sarana pengembangan diri mahasiswa ke arah perluasan wawasan dan peningkatan kecendekiawanan serta integritas kepribadian untuk mencapai tujuan pendidikan tinggi. Pada pasal lima juga menjelaskan bahwa organisasi kemahasiswaan intra perguruan tinggi sebagai sarana dan wadah: Pertama, perwakilan mahasiswa tingkat perguruan tinggi untuk menampung dan menyalurkan aspirasi mahasiswa, menetapkan garis-garis besar program dan kegiatan kemahasiswaan. Kedua, pelaksanaan kegiatan kemahasiswaan. Ketiga, Komunikasi antar mahasiswa. Keempat, Pengembangan potensi jati diri mahasiswa sebagai insan akademis, calon ilmuwan dan intelektual yang berguna di masa depan. Kelima, Pengembangan pelatihan keterampilan organisasi, manajemen dan kepemimpinan mahasiswa. Keenam, pembinaan dan pengembangan kader-kader bangsa yang dalam melanjutkan kesinambungan pembangunan sosial. Ketuju, untuk memelihara dan mengembangkan ilmu dan teknologi yang dilandasi oleh norma-norma agama, akademis, etika, moral dan wawasan kebangsaan.

Organisasi adalah suatu sistem yang terdiri dari pola aktivitas kerjasama yang dilakukan secara teratur dan berulang-ulang oleh sekelompok orang untuk mencapai suatu tujuan (Gitosudarmo, 2000:1). Menurut Nawawi, organisasi terdiri dari dua segi yaitu pengertian organisasi secara statis dan dinamis yaitu: Secara statis, organisasi adalah wadah berhimpun sejumlah manusia karena 
memiliki kepentingan yang sama. Statis dalam arti bahwa setiap organisasi memiliki struktur yang cenderung tidak berubah-ubah disamping itu posisi, status dan jabatan juga cenderung permanen. Secara dinamis, proses kerjasama sejumlah manusia (dua orang atau lebih) untuk mencapai tujuan bersama. Dinamis dalam arti bahwa kerjasama berlangsung secara berkelanjutan atau proses yang selalu mungkin menjadi lebih efektif dan efesien, sebaliknya juga semakin kurang efektif atau kurang efesien. Disamping itu interaksi antar manusia didalam organisasi tidak pernah sama dari waktu ke waktu. (Nawawi, 2000: 8).

Pada dasarnya organisasi memiliki empat unsur pokok (Nawawi, 2000: 8) yang terdiri dari: Manusia. Unsur ini dari segi jumlah terdiri dari dua orang atau lebih. Filsafat. Manusia yang menghimpun diri dalam organisasi, dengan hakekat kemanusiaannya, menjalani kehidupan bersama berdasarkan filsafat yang sama, sehingga memungkinkan terwujudnya kerjasama. Proses organisasi sebagai perwujudan interaksi antar manusia yang menghasilkan kerjasama, tidak pernah berhenti selama manusia berhimpun didalamnya. Oleh sebab itu kerjasama tersebut sebagai kegiatan yang berlangsung sebagai proses, dan terakhir tujuan. Organisasi didirikan manusia adalah karena kesamaan kepentingan, baik dalam rangka mewujudkan hakekat kemanusiannya maupun secara berkelanjutan untuk memenuhi kebutuhannya. Setiap organisasi terdapat beberapa orang yang bertanggung jawab untuk mengkoordinasikan sejumlah orang yang bekerjasama di dalam aktivitasnya. Selain itu, orang yang bertanggung jawab tersebut harus mengkoordinasikan aneka ragam kegiatan yang mempunyai kepentingan yang berbeda.

Organisasi kemahasiswaan dapat ditemui dalam setiap tingkat, baik di jurusan, fakultas dan kampus. Organisasi kemahasiswaan dapat berupa Himpunan Mahasiswa Jurusan (HMJ), Badan Eksekutif Mahasiswa (BEM), Dewan Perwakilan Mahasiswa (DPM), Unit Kegiatan Khusus (UKK), Unit Kegiatan Mahasiswa (UKM) dan Badan Otonom (BO). Setiap organisasi kemahasiswaan memiliki program kerja jangka panjang dan jangka pendek yang akan dilaksanakan sesuai dengan masa jabatan yang tercantum di dalam AD/ART. Dalam pelaksanaan program kerja setiap organisasi memiliki sejumlah 
P-ISSN 2580 - 7781

E-ISSN $2615-3238$

departemen atau dinas. Departemen atau dinas merupakan wadah bagi anggota organisasi sebagai perumus dan pelaksana program kerja.

Himpunan Mahasiswa Sosiologi merupakan salah satu organisasi yang berada di dalam lingkup perguruan tinggi Universitas Sriwijaya di tingkat jurusan. Himpunan mahasiswa sosiologi memiliki delapan dinas yang terdiri dari dinas pengembangan dan pemberdayaan sumber daya manusia (PPSDM), dinas pengembangan potensi mahasiswa (PPM), dinas komunikasi dan informasi (KOMINFO), dinas kajian ilmiah, dinas hubungan mahasiswa (HUMAS), dinas perekonomian, dinas sosial masyarakat (SOSMAS), dan dinas kesekretariatan (KESTARI). Kedelapan dinas memilki program kerja masing-masing.

Saat ini dunia mengalami masa pandemi covid - 19. Dikutip dari website Kementrian Kesehatan, covid 19 atau coronavirus merupakan keluarga besar virus yang menyebabkan penyakit pada manusia dan hewan. Pada manusia biasanya menyebabkan penyakit infeksi saluran pernapasan, mulai flu biasa hingga penyakit yang serius seperti Middle East Repiratory Syndrome (MERS) dan Sindrom Pernafasan Akut Berat atau Severe Acute Respiratory Syndrome (SARS). Coronavirus jenis baru yang ditemukan di Wuhan Cina, pada Desember 2019. Kemudian diberi nama Severe Acute Respiratory Syndrome Coronavirus 2 (SARSCOV2) dan menyebabkan penyakit Coronavirus Diesease - 2019 (COVID-19)

Indonesia merupakan salah satu negara yang berdampak terhadap pandemi covid - 19. Menurut data Satgas Penanganan Covid - 19 pada tanggal 17 Oktober 2020, angka positif covid - 19 telah menembus angka 357.762 orang, dengan pasien sembuh 281.592 orang dan korban jiwa sebanyak 12.431 orang. Setiap harinya angka positif mengalami peningkatan secara signifikan. Pandemi covid 19 memberikan dampak buruk dalam berbagai sektor. Dalam penanganannya pemerintah membuat berbagai kebijakan, seperti kebijakan pembatasan sosial berskala besar dan bekerja/belajar di rumah.

Pada masa pandemi komunikasi primer dibatasi oleh kebijakan yang dibuat oleh pemerintah. Komunikasi sekunder menjadi solusi untuk melakukan aktivitas sehari - hari. Walaupun tidak sama persis, tetapi melalui komunikasi sekunder dapat membantu pelaksanaan kegiatan yang telah direncanakan. Media sosial 
menjadi jembatan penghubung antar individu dalam berkerjasama, berbagi, berkomunikasi dan sebagai membentuk hubungan sosial secara virtual.

Di masa pandemi covid - 19 pelaksanakan program kerja himpunan mahasiswa sosiologi terkendala oleh kebijakan-kebijakan yang telah ditetapkan pemerintah. Hal ini membuat beberapa program kerja berubah pada sistem pelaksanaannya. Perubahan ini dilakukan dengan melaksanakan program kerja secara online. Aplikasi seperti zoom meeting dan google meeting merupakan media yang digunakan dalam menjalankan program kerja. Aplikasi virtual ini mampu membantu dan mempermudah manusia. Selain itu, lebih efektif dan efisien dalam penggunaannya. Manusia dapat melakukan video conference dimana pun dan dalam keadaan apapun. Inilah kemudahan-kemudahan yang ditawarkan dalam teknologi virtual. Namun, tidak semua program kerja dilaksanakan secara virtual terdapat program-program yang gagal untuk dilkasanakan selama pandemi covid - 19 .

Di dalam organisasi akan mengenal dengan namanya kinerja. Kinerja adalah hasil dari suatu proses yang mengacu dan diukur selama periode waktu tertentu berdasarkan ketentuan atau kesepakatan yang telah ditetapkan sebelumnya (Edision, 2016: 190). Secara umum kinerja dapat diartikan sebagai keseluruhan proses kerja dari seseorang yang hasilnya dapat dijadikan landasan sebagai penentu berhasil atau tidaknya suatu pekerjaan. Kinerja yang dicapai oleh sebuah tim atau kelompok akan lebih baik daripada kinerja individu disuatu organisasi ataupun suatu perusahaan. Walaupun begitu, kerjasama antar kelompok pula harus efektif agar memberikan kontribusi yang bagi hasil kerja dalam suatu lembaga. Kinerja suatu organisasi di nilai dari terlaksana atau tidaknya suatu program kerja. Pandemi covid - 19 memberi dampak buruk, dimana akan menghambat dalam proses pelaksanaan program kerja yang telah disusun dan direncanakan setiap dinas di Himpunan Mahasiswa Sosiologi. Dalam penelitian ini akan melakukan analisis mengenai kinerja Himpunan Mahasiswa Sosiologi selama pandemi covid -19 . 
P-ISSN 2580 - 7781

E-ISSN $2615-3238$

\section{METODE PENELITIAN}

Metode penelitian yang digunakan adalah kualitatif. Metode kualitatif digunakan untuk mendapatkan data yang mendalam, suatu data yang mengandung makna, data yang sebenarnya dan data yang pasti (Sugiyono, 2013: 3). Penelitian ini dilakukan secara online di ruang lingkup Himpunan Mahasiswa Sosiologi, Fakultas Ilmu Sosial dan Ilmu Politik, Universitas Sriwijaya. Objek penelitian adalah civitas akademik yang tergabung dalam himpunan mahasiswa sosiologi. Penentuan informan dilakukan dengan teknik purposive sampling, yaitu teknik pengambilan sampel sumber data dengan pertimbangan tertentu. Informan yang dipilih, terdiri dari bupati Himpunan Mahasisiswa Sosiologi dan badan pengurus harian Himpunan Mahasiswa Sosiologi.

Teknik pengumpulan data dilakukan dengan wawancara mendalam secara online. Wawancara berdasarkan pada pedoman wawancara yang telah dibuat. Analisis data kualitatif bersifat induktif, yaitu suatu analisis berdasarkan data yang diperoleh, selanjutnya dikembangkan menjadi hipotesis dan dicarikan data lagi secara berulang-ulang sehingga dapat disimpulkan apakah hipotesis tersebut diterima atau ditolak berdasarkan data yang terkumpul.

\section{HASIL PENELITIAN DAN PEMBAHASAN}

Kinerja merupakan hasil kerja yang dilihat dari sisi kualitas maupun kuantitas yang diperoleh pada pelaksanaan tugas sesuai tanggung jawab yang dipegang setiap individu maupun kelompok. Tercapainya kinerja yang baik dibutuhkan kerjasama, komunikasi dan kooordinasi setiap bagian di dalam organisasi. Hasil penelitian menggambarkan bahwa kinerja Himpunan Mahasiswa Sosiologi mengalami penurunan selama masa pandemi covid - 19. Penurunan ini diuji melalui indikator - indikator dalam mengukur kinerja menurut Setiawan (2014 : 147) dari hasil wawancara: Pertama, ketepatan penyelesaian tugas. Setiap dinas pada Himpunan Mahasiswa Sosiologi memilki jadwal (timeline) yang telah ditetapkan sesuai dengan kesepakatan bersama. Melalui jadwal tersebut, diharapkan membantu dalam persiapan pelaksanaan program kerja. Selain itu, dengan adanya jadwal antar agenda dinas dapat terkoordinasi, sehingga menghindari terjadi agenda ganda dalam satu harinya. Dimasa pandemi ini, 
program kerja terjadi pengunduran dalam melaksanakan program kerja. Pengunduran ini dilakukan karena kurang persiapan dari dinas maupun panitia dalam menjalankan program kerja di masa pandemi, sehingga dinas belum menyelesaikan tanggung jawab terhadap program kerja yang telah dijadwalkan.

Kedua, kesesuaian jam kerja. Persiapan dalam menjalankan program kerja menjadi sesuatu hal penting. Dengan segala persiapan yang telah dilakukan harapannya mampu melaksanakan program kerja secara baik. Namun, dalam menjalankan program kerja secara online sering terjadi berbagai kendala, misalnya gangguan jaringan. Gangguan jaringan atau teknis membuat ketidaksesuaian jam kerja/ waktu dalam melaksanakan program kerja. Ketiga, tingkat kehadiran. Kehadiran anggota himpunan dalam mempersiapkan atau menjadi pelaksana menjadi kriteria selanjutnya dalam mengukur kinerja dari himpunan mahasiswa sosiologi. Dari hasil wawancara, partisipasi anggota himpunan selama masa pandemi terbilang kecil. Hal ini dipengaruhi oleh beberapa faktor, diantaranya banyak anggota himpunan yang terkendala oleh kesibukan - kesibukan di rumah. Selain itu, masalah jaringan dan motivasi yang kecil dari anggota menjadi faktor yang membuat angka kehadiran atau partisipasi dalam mempersiapkan maupun melaksanakan program kerja.

Keempat, kerja sama. Kerja sama diperlukan dalam melaksanakan program kerja himpunan. Melalui kerja sama, maka kelompok dapat mencapai tujuan dengan mudah. Selama masa pandemi, kerja sama antar panitia pelaksana berjalan cukup baik. Walaupun pada awal pelaksanakan program kerja membutuhkan penyesuaian, terutama dalam koordinasi antar bidang pelaksana. Kelima, kepuasan kerja. rasa senang dan gembira menjadi bentuk kepuasan tersendiri bagi panitia pelaksana program kerja. Informan mengatakan bahwa mereka puas dengan capaian program kerja. Walaupun terdapat kendala dalam proses pelaksanaan. Mereka merasa bangga dan apresiasi dengan pelaksanaan program kerja yang telah dicapai saat masa pandemi covid -19 .

Terhitung dari bulan Maret hingga sekaramg terdapat lima program kerja yang telah terlaksana secara online, diantaranya; kunjungan kerja lintas organisasi, lomba esai nasioal, webinar, bertemuan antara pengurus harian organisasi dengan 
P-ISSN 2580 - 7781

E-ISSN $2615-3238$

mahasiswa baru sosiologi dan aksi penggalangan dana. Program kerja yang telah terlaksana merupakan upaya-upaya yang dilakukan oleh Himpunan Mahasiswa Sosiologi dalam merubah sistem pelaksanaan program kerjadari offline ke online. Perubahan dalam sistem pelaksanaan program kerja membutuhkan penyesuaianpenyesuaian bagi Himpunan Mahasiswa Sosiologi. Penyesuaian ini terutama dalam mempersiapkan pelaksanaan program kerja, bahkan dalam pelaksanaan program kerja diperlukan back up oleh sejumlah badan pengurus harian dalam satu program kerja.

Dalam menjalankan program kerja terdapat faktor - faktor yang dihadapi Himpunan Mahasiswa Sosiologi diantaranya: pertama, kurangnya massa dalam menjalankan program kerja. Hal ini disebabkan banyak anggota Himpunan Mahasiswa Sosiologi yang berada di daerah. Walaupun dilakukan secara online, fasilitas jaringan internet di daerah kurang memadahi. Jarinagan internet diperlukan sebagai penghubung dalam persiapan dan pelaksanaan, sehingga yang terjadi dalam pelaksanaannya terdapat ketidaksesuaian dari harapan panitia. Kedua, kurangnnya koordinasi antar panitia. Koordinasi diperlukan dalam pelaksanaan program kerja. Melalui koordinasi antar panitia secara intensif, maka pelaksanaan program kerja dapat berjalan dengan baik. Namun, faktanya dalam persiapan pelaksanaan terjadi missing communication yang membuat program kerja kurang terkoordinasi dengan baik. Ketiga, pendanaan program kerja dan birokrasi. Dalam pelaksanaan program kerja membutuhkan dana, walaupun online panitia pelaksana membutuhkan dalam membeli kuota internet. Dana dalam pelaksanaan program kerja sebenarnya telah disediakan oleh fakultas. Namun, dalam pengajuan permohonan dan pengambilan dana memerlukan waktu yang lama, sehingga terdapat program kerja terhambat, bahkan panitia pelaksana mengeluarkan uang pribadi dalam pelaksanaan program kerja. Dari ketiga dampak tersebut mengakibatkan terjadinya pengunduran program kerja, khususnya program kerja yang tidak dapat dilakukan secara online seperti bakti desa, festival ilmiah dan kunjungan ke panti asuhan yang telah direnacanakan sebelumnya. Kendala - kendala ini dapat pula menjadi tolak ukur dari kinerja, selain indikator menurut Setiawan yang telah dijelaskan pada pembahasan sebelumnya. 
Secara umum, terdapat lima dinas dari delapan dinas yang secara intensif melakukan program kerja Himpunan Mahasiswa Sosiologi selama masa pandemi covid - 19. Penggunaan teknologi informasi dan komunikasi menjadi upaya dalam pelaksanaan program kerja. Walaupun perlu berbagai penyesuaian dalam melaksanakan program kerja secara online. Dari hasil penelitian yang didapat bahwa kualitas kinerja yang dilakukan oleh Himpunan Mahasiswa Sosiologi memerlukan perbaikan dan penyesuaian program kerja dengan kondisi saat ini, sehingga dapat diharapkan mengaktifkan kembali kegiatan-kegiatan di Himpunan Mahasiswa Sosiologi di masa pandemi covid - 19 .

\section{KESIMPULAN}

Dalam pencegahan penyebarana covid - 19 pemerintah telah menetapkan kebijakan pembatasan sosial berskala besar dan bekerja/belajar di rumah. Kebijakan yang telah dibuat mempengaruhi aktivitas organisasi kemahasiswaan di kampus. Organisasi kemahasiswaan seperti Himpunan Mahasiswa Sosiologi tidak dapat dalam menjalankan progam kerja secara intensif. Terdapat program kerja yang tidak dapat dilaksanakan di masa pandemi covid - 19, walaupun telah diubah dalam sistem pelaksanaannya. Berdasarkan hasil analisa maka diperoleh bahwa kinerja dari himpunan mahasiswa sosiologi mengalami penurunan. Analisa mengenai kinerja ini dapat dilihat dari kualitas Himpunan Mahasiswa Sosiologi dalam menjalankan program kerja yang telah disusun sebelumnya. Di dalam hasil penelitian dan pembahasan menjelaskan bahwa pelaksanaan program kerja di masa pandemi covid - 19 yang dilakukan Himpunan Mahasiswa Sosiologi mengalami berbagai kendala, baik dalam persiapaan maupun proses pelaksanaan program kerja.. Pengubahan sistem pelaksanaan dari offline dan online membuat Himpunan Mahasiswa Sosiologi memerlukan penyesuaian dalam menjalankan program kerja. Sehingga terdapat program kerja yang dapat dilaksanakan maupun tidak dapat dilaksanakan selama satu periode ini. 
P-ISSN 2580 - 7781

E-ISSN $2615-3238$

\section{DAFTAR PUSTAKA}

Edison. (2016). Manajemen Sumber Daya Manusia. Bandung: Alfabeta. Gitosudarmo, I. (2000). Perilaku Keorganisasian. Yogyakarta: BPFE.

Kementerian Kesehatan Republik Indonesia. (2020). Pertanyaan Dan Jawaban Terkait COVID - 19. Retrieved from https://www.kemkes.go.id/folder /view/full-content/structure-faq.html

Keputusan Menteri Pendidikan Dan Kebudayaan Republik Indonesia Nomor 155/U/1998 Tentang Pedoman Umum Organisasi Kemahasiswaan Di Perguruan Tinggi.

Nawawi, H. (2000). Manajemen Sumber Daya Manusia. Yogyakarta: Gajah Mada University Press.

Setiawan, F., \& Dewi, K. (2014). Pengaruh Kompensasi Dan Lingkungan Kerjaterhadap Kinerja Karyawan Pada Cv. Berkat Anugrah. Ejurnal Manajemen Universitas Udayana, 3(5).

Sugiyono. (2013). Memahami Penelitian Kualitatif. Bandung: Alfabeta.

Satgas Penanganan Covid - 19. (2020). Data Sebaran. Retrieved from https://covid19.go.id/ 